profession to the medical or surgical specialist existed in this country? The biographies of British ophthalmologists which have appeared from time to time in THE BRITISH JOURNAL OF OPHTHALMOLOGY show this as regards ophthalmology. We learn a great deal from this article as to the stages in the advancement of knowledge in America, and it is almost certain that if a similar article were written for this country, it would be found that we also had made progress by similar stages from ignorance to what we choose to call knowledge. Yet, what will our successors have to say about it ?

\title{
The Halifax Disaster
}

In the April number of the American Journal of Ophthalmology a graphic account is given by our colleague, Captain F. Tooke, of Montreal, of his experiences after the recent Halifax disaster. It will well repay perusal. On short notice he left Montreal for Halifax accompanied by a member of the nursing staff of the Royal Victoria Hospital. After a couple of nights spent on the train Halifax was reached. The roof of the railway station had fallen in ; innumerable cars and trucks were wrecked on the sidings, and the travellers were compelled to make their way through a sea of broken glass and over countless obstacles, chiefly wreckage and coffins. The city was wrapped in silence, and the streets were empty. Halifax seemed to be a city of the dead. An area equal to one and a half miles square was laid flat; not a building was left entire, even large trees being shattered. There was not one building in the city without broken glass. Some idea of the force of the explosion may be gathered from the bald statement that the massive anchor of the "Mont Blanc," the ammunition ship laden with petrol and tri-nitro-toluol that exploded after collision with the Belgian relief steamer "Imo," was found three miles from the scene of the disaster. Captain Tooke estimates that 25 per cent. of the casualties were eye cases. The great proportion of these injuries is to be explained by the fact that the glare of the burning petrol on the "Mont Blanc" and the ringing of the fire alarms had drawn many persons to the windows, and when the explosion came later and the glass was blown inward many eyes were damaged. It was a fortunate circumstance, perhaps, that double windows had not been put up for the winter. Captain Tooke gives a list of 48 eye injuries, in many of which operations were necessary. The injuries were from broken glass, and were often associated with incised wounds of the head, face, and neck due to a similar cause, which were almost invariably septic. 1,500 units of antitetanic serum were given, but only on the fifth day after the explosion, since a large enough supply could not be obtained at first. It is satisfactory 
to note that not a single case of tetanus developed. Neither spreading gangrene nor erysipelas was met with. The writer expresses an opinion that about 200 persons have been or will be blinded as the result of the explosion. In conclusion, he pays a handsome tribute to the heroism of the people of Halifax, and to the generous response made by the American medical profession and the American public in conveying prompt help to the stricken community.

\section{OBITUARY}

We learn with sorrow of the sudden death, on July 27, of Frederick Eustace Batten, M.D., F.R.C.P., aged 52 years, from haemorrhage and collapse shortly after a severe operation. Born at Plymouth he was the third son of the late John Winterbotham Batten, K.C. He was educated at Westminster and at Trinity College, Cambridge, and received his medical training at St. Bartholomew's Hospital, London. Batten's name was wellknown to ophthalmic surgeons, especially from his researches on certain familial diseases of the eye and of the nervous system. The affection to which he devoted most attention was the one first described clinically by his brother, Rayner D. Batten in 1897 (Trans. Ophthal. Soc. U.K., Vol. XVII, p. 48). His first contribution on "Family cerebral degeneration with macular change," was published in the Quarterly Journal of Medicine of July, 1914, and dealt with a family of five children, three of whom were affected with a progressive disease leading to dementia, blindness, and paralysis, one of the patients showing macular changes. The affected children died at ages ranging from four to eight years. In one case a microscopical examination showed diffuse degenerative changes in the ganglion cells of the cerebrum, cerebellum, and spinal cord. Batten's next communication was made in 1915 in the Section of Ophthalmology of the Royal Society of Medicine conjointly with M. S. Mayou, and dealt more especially with the pathology of the eyes and of the central nervous system in two cases of the kind. Batten selected the same subject for an address he delivered before the Oxford Ophthalmological Congress on July 13, 1916. Briefly, he took the view that the affection was a form of Tay-Sachs's disease, but occurring in a later period of life. Although not a member of the Ophthalmological Society of the United Kingdom at the time of his death, he had served on the Council of the Society from 1904 to 1906 and as Secretary from 1906 to 1909. Batten held the posts of out-patient physician to the National Hospital for the Paralysed and Epileptic, Queen Square, physician 